\title{
Effect of Using E-Mind Maps on the level of Technical and Numerical Performance in Walking Event for Girls at Faculty of Physical Education, Zagazig *Dr /Ola Al-Said Elewa Fouda
}

\section{Introduction and research problem:}

Mind maps created in seventies in (1971) and the $1^{\text {st }}$ mind maps strategy appeared widely in (1974) that simplified the presentation of information as it shortened the text by $(90 \%)$ and came from Buzan's ideas (19: 59).

Buzan (2007) indicated that mind maps strategy depended on drawing a map or figure similar to how the mind read information where the center was the main idea and branches were emerged according to profession or classification. Mind maps could be compared with those of the city as the mind map center was the city center representing the idea of more importance in the topic under studying and the main roads branched from the city center representing main ideas in the thinking processes and secondary roads representing secondary ideas (21:83).
Mind maps are
considered as a final
organizational thinking tool
working to stimulate or to provoke thinking. They are very simple as the mind map is considered as the simplest method to enter data into the brain and to recover such data; hence, it is a creative and effective means to record remarks (26: 138)(27: 93).

E-mind maps represent a strategy of learning depending on the idea of active learning where the learner takes part in it as he forms an imagination on concepts and relationships connecting between them and to try to express them in an abstract form briefly in a form of graphics and linear configurations forming a mental mind map to be executed manually with a paper and a pencil called manual method or by a specialized computer programs comprised of several tools

"Lecturer, Dept. of Field and Track Events, Faculty of Physical Education for Girls, Zagazig University 
enabling the learner to place an imagination of those concepts on the computer screen (8:156).

E-mind maps are designed depending on computer programs; however, graphic skills are not a must for their users as they automatically create maps with streamline curves for branches. They allow dragging and shedding images from the graphic library. Also they provide other possibilities such as re-arranging topics and ideas and updating the map content when necessary making them a strong tool for follow-up and progress constantly. They give the chance for cooperative work that is not allowed by traditional mind maps as it is possible to make an e-mind map and to send it by e-mail to others in the cooperative work team (8:166-168).

Athletic walking event is considered as one of track events built on one motor basis and its steps are performed in the form of double steps together with considering the technical phases of performance as the international law places restrictions that artistry should be connected to performance in walking event for running and wrong performance in walking event will cause the competitor to be eliminated from the event. Also athletic walking event is considered as one of the sports activities distinguished as a sports competitive activity having its importance in championships and Olympic sessions to acquire it a special importance that is clear in considering the use of methods and techniques of scientific researches and making use of results of studies and scientific researches introduced the applied aspects to increase the efficiency of performance and numerical achievement of walking competitors and how to develop and to improve it to contribute to register new numbers through the use of methods and techniques that contribute to upgrade the physical, functional and psychological levels and athletic walking event is a thrilling competitive Olympic sport (7:99).

Through her work in the field of teaching field and track events for girls in the $2^{\text {nd }}$ grade at Faculty of Physical Education for Girls, Zagazig 
University, the researcher noticed that the level of technical and numerical performance was decreased in athletic walking event and she related that to the organizers of the educational process who have used orders-learning technique (the traditional method) built on presenting verbal explanation of the educational technical and legal aspects of the walking event then presenting a practical example for phases of the technical performance of athletic walking without any positive participation of girls in the educational position in addition to the large numerical density of students in practical lectures and consequently the burden is increased on the teacher.

Meanwhile reference survey of scientific studies in the field of mind maps and learning motor skills in individual and team sports such as the study of: Lila Sharaf ElDin Emam $(2012)_{(5)}$, Tamer Gamal Arafa (2015)(2), Joseph Nagy Adib (2015)(22), Sohail Mohammed Al-Sayed $(2015)_{(24)}$, Shady Mohammed Al-Araby $\quad(2015)_{(25)}$, Nehad Mohammed Elwan and Nabil
Kazem Heribd $(2015)_{(16)}$, the researcher noticed that there was no scientific study to the knowledge of the researcher introduced e-mind maps and learning athletic walking event.

From the foregoing the researcher decided to study the effect of using e-mind maps on the level of technical and numerical performance in athletic walking event for girls in the $2^{\text {nd }}$ grade at Faculty of Physical Education for Girls, Zagazig University.

Research objectives:

The purpose of the current research was to place a proposed educational program by using a strategy of e-mind maps and to know its effect on the following:

1- The level of technical performance in athletic walking event for girls in the $2^{\text {nd }}$ grade at Faculty of Physical Education for Girls, Zagazig University.

2- $\quad$ The numerical level in athletic walking event for girls in the $2^{\text {nd }}$ grade at Faculty of Physical Education for Girls, Zagazig University.

\section{Research hypotheses:}

1- There are significant differences between means of the pre and post-measurements of the experimental group in 
the level of technical and numerical performance in athletic walking event in favor of the post-measurement.

2- There are significant differences between means of the pre and post-measurements of the control group in the level of technical and numerical performance in athletic walking event in favor of the post-measurement.

3- There are significant differences between means of the two post-measurements of the experimental and control groups in the level of technical and numerical performance in athletic walking event in favor of the experimental group.

Research procedures:

Method:

The researcher applied the experimental method as it suited the nature of the current research through the experimental layout of two groups representing the experimental and control groups and using the pre and post-measurements.

Research people:

It included girls in the $2^{\text {nd }}$ grade at Faculty of Physical Education for Girls, Zagazig
University of (340) girls in the $2^{\text {nd }}$ college term in 2014/2015 academic year.

Sample:

It was selected intentionally from girls in the $2^{\text {nd }}$ grade at Faculty of Physical Education for Girls, Zagazig University in the $2^{\text {nd }}$ college term in 2014/2015 academic year of total of (340) girls where (45) girls were chosen by $(13.24 \%)$. (15) girls were excluded as a pilot study sample, hence, the main research sample became (30) girls who were divided into two equal groups representing the experimental and control groups of (15) girls each.

The researcher
computed
coefficients of individuals of the research sample in some variables that may effect on the experimental variable such as age, height, weight, intelligence, some physical abilities associated with athletic walking event and the level of technical and numerical performance in athletic walking event as shown in Tables (1\&2).

\section{Table (1)}

Skewness coefficients of the sample individuals in rates of growth (age, height, weight, intelligence) under investigation $n=45$

\begin{tabular}{l|l|l}
\hline Variables & Units & $\mathbf{X}^{-}$ \\
\hline
\end{tabular}

Assiut Journal For Sport Science Arts 


\begin{tabular}{|c|c|c|c|c|c|}
\hline & & & & & ness \\
\hline Age & $\mathrm{Yr}$ & 19.5. &. .71 & 19.4. &. .10 \\
\hline Height & $\mathrm{cm}$ & 177.00 & $0 . \leqslant 9$ & $170 .$. &.$\wedge r$ \\
\hline Weight & $\mathrm{kg}$ & 70.10 & 0.17 & $7 \leqslant .0$. &.$\vee 1$ \\
\hline Intelligence & Score & Y9.0. & $\varepsilon . \wedge 1$ & r^... & .98 \\
\hline
\end{tabular}

Data in Table (1) show that skew ness coefficients in rates of growth (age, height, weight, intelligence) range from $(0.71$ to 0.94$)$ i.e. they fall between $( \pm 3)$ indicating that the sample individuals are distributed normally in such variables.

\section{Table (2)}

Normality of distributing the sample individuals in special physical abilities and the level of technical and numerical performance $n=45$

\begin{tabular}{|c|c|c|c|c|c|}
\hline Variables & Units & $\mathbf{X}^{-}$ & SD & $\mathbf{M}$ & $\begin{array}{c}\text { Skew } \\
\text { ness } \\
\text { coef. }\end{array}$ \\
\hline $\begin{array}{l}\text { Cardiorespiratory } \\
\text { endurance, running } 800 \mathrm{~m} \text {. }\end{array}$ & min. & r.vq & $\because 1 \varepsilon$ & r.Ar & $.7 \varepsilon_{-}$ \\
\hline Strength of muscles of legs & $\mathrm{kg}$ & 91.0 & $\sum .71$ & $9 \cdot \ldots$ & .91 \\
\hline Strength of back muscles & $\mathrm{kg}$ & $10 . \leqslant V$ & 0.11 & Aะ.YO & $\because \times 1$ \\
\hline Transitional speed, 50m dash. & $\min$. & 9.71 &.$V T$ & $9 . \leqslant 0$ & $\cdot .77$ \\
\hline Aperture of calipers & $\mathrm{cm}$. & T. 0. & $\varepsilon .91$ & $r \cdot \cdots$ & $.9 Y$ \\
\hline $\begin{array}{l}\text { Zigzag running with } \\
\text { Barrow method }\end{array}$ & $\min$. & $9 . \wedge r$ & $\because 0 \leqslant$ & 9.71 & $\cdot .7 V$ \\
\hline Stand balance & $\min$. & $1 Y .91$ & I.Ar & $1 Y . \varepsilon \varepsilon$ & $\because V V$ \\
\hline $\begin{array}{l}\text { The level of technical } \\
\text { performance of athletic } \\
\text { walking event. }\end{array}$ & Score & 1.49 & $1 \ldots$ & $1 . \cdots$ & $\cdot \wedge \vee$ \\
\hline $\begin{array}{l}\text { The numerical level in } \\
\text { athletic walking event. }\end{array}$ & $\min$. & $|r . r|$ & $1 . \leqslant \varepsilon$ & IT. & $\cdot r \Lambda$ \\
\hline $\begin{array}{l}\text { Data in Table } \\
\text { illustrate that values of sk } \\
\text { ness coefficients in sol }\end{array}$ & & $\begin{array}{l}\text { speci } \\
\text { techr } \\
\text { perfo }\end{array}$ & $\begin{array}{l}\text { abilitic } \\
\text { al } \\
\text { nance }\end{array}$ & $\begin{array}{l}\text { and th } \\
\text { ind } n\end{array}$ & $\begin{array}{l}\text { level of } \\
\text { Imerical } \\
\text { athletic }\end{array}$ \\
\hline \multicolumn{3}{|c|}{ Assiut Journal For Sport Science Arts } & & & \\
\hline
\end{tabular}


walking event range from (0.64 to 0.98$)$ i.e. they fall between $( \pm 3)$ indicating that the sample individuals are distributed normally in such variables.

Equivalence between the experimental and control groups were computed in variables under investigation after carrying out scientific treatments viz. validity and stability for tests under investigation as shown in Tables (3\&4).

Table (3)

Significance of differences between the experimental and control groups in rates of growth (age, height, weight, intelligence)

\begin{tabular}{|c|c|c|c|c|c|c|}
\hline \multirow[t]{2}{*}{ Variables } & \multirow[t]{2}{*}{ Units } & \multicolumn{2}{|c|}{$\begin{array}{c}\text { Experimental } \\
\text { group } n=15\end{array}$} & \multicolumn{2}{|c|}{$\begin{array}{l}\text { Control } \\
\text { group } \\
\mathrm{N}=15 \\
\end{array}$} & \multirow[t]{2}{*}{$\begin{array}{c}\text { Value } \\
\text { of } t\end{array}$} \\
\hline & & $X^{-}$ & SD & $X^{-}$ & $\mathrm{SD}$ & \\
\hline Age & $\mathrm{Yr}$ & 19.2. & .00 & 19.4. & $.0 Y$ &..$\leqslant 9$ \\
\hline Height & $\mathrm{cm}$ & 177.10 & $\Sigma . \wedge r$ & $170 \ldots$ & $\leqslant .0 \leqslant$ &.$V^{\prime \prime}$ \\
\hline Weight & $\mathrm{kg}$ & 70.5. & $\{.71$ & $T \leq . Y_{0}$ & $\leqslant . \leqslant 9$ & 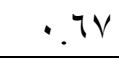 \\
\hline Intelligence & Score & Y9.0. & r. $9 v$ & rq... & ะ.11 & rr. \\
\hline
\end{tabular}

Tabulated $\mathrm{t}$ value at 0.05 significance level $=2.048$

Data in Table (3) illustrate that there is no significance difference at 0.05 level of significance between the experimental and control groups in rates of growth (age, height, weight, intelligence) indicating that the two research groups are equivalent in such variables. 
Table (4)

Significance of differences between the experimental and control groups in special physical abilities and the level of technical and numerical performance in athletic walking event

\begin{tabular}{|c|c|c|c|c|c|c|}
\hline \multirow{2}{*}{\begin{tabular}{l}
\multicolumn{1}{c}{ Variables } \\
Cardiorespiratory \\
endurance, running \\
$\mathbf{8 0 0 m}$.
\end{tabular}} & \multirow{2}{*}{$\begin{array}{l}\text { Units } \\
\text { min. }\end{array}$} & \multicolumn{2}{|c|}{$\begin{array}{c}\begin{array}{c}\text { Experimental group } \\
\mathrm{n}=15\end{array} \\
\end{array}$} & \multicolumn{2}{|c|}{$\begin{array}{c}\begin{array}{c}\text { Control group } \\
n=15\end{array} \\
\end{array}$} & \multirow[b]{2}{*}{$\begin{array}{l}\text { Value } \\
\text { of } t\end{array}$} \\
\hline & & $\mathbf{X}^{-}$ & SD & $\mathbf{X}^{-}$ & SD & \\
\hline $\begin{array}{l}\text { Strength of muscles of } \\
\text { legs }\end{array}$ & $\mathrm{kg}$ & T.Ar &. .11 & r.v &. .14 &. .79 \\
\hline $\begin{array}{l}\text { Strength of back } \\
\text { muscles }\end{array}$ & $\mathrm{kg}$ & $9 . . \varepsilon$. & T.VT & $91 . r$. & r.^o & .07 \\
\hline $\begin{array}{l}\text { Transitional speed, } 50 \mathrm{~m} \\
\text { dash. }\end{array}$ & $\min$ & No.r. & L.T & $1 \leq .0$ & $\varepsilon .7 \varepsilon$ & $\because \leqslant 1$ \\
\hline Aperture of calipers & $\mathrm{cm}$. & 9.71 & $\because \varepsilon 1$ & 9.74 & $\cdot . \leqslant r$ & $\cdot r \Lambda$ \\
\hline $\begin{array}{l}\text { Zigzag running with } \\
\text { Barrow method }\end{array}$ & $\min$. & Tr. ro & $\varepsilon . V \varepsilon$ & T. 0. & $\varepsilon .01$ & $\cdot \varepsilon r$ \\
\hline Stand balance & $\min$. & 9.11 &. .99 & $9 . \wedge r$ & $.0 \leqslant$ & $\cdot . Y \Lambda$ \\
\hline $\begin{array}{l}\text { The level of technical } \\
\text { performance of athletic } \\
\text { walking event. }\end{array}$ & Score & IT.TY & 1.17 & IY.AN & $1 . r 0$ & $.0 \mathrm{~V}$ \\
\hline $\begin{array}{l}\text { The numerical level in } \\
\text { athletic walking event }\end{array}$ & $\min$. & $1 . r$. & $\cdot . \wedge r$ & $1 . r V$ & $\cdot .91$ & $\because r$ \\
\hline
\end{tabular}

Tabulated $t$ value at 0.05 significance level $=2.048$

Data in Table (4) demonstrate that there is no significant difference at 0.05 level of significance between the experimental and control groups in special physical abilities and the level of technical and numerical performance in athletic walking event indicating that the two research groups are equivalent in such variables.

Tools of collecting data:

They are divided into the following:

I. Devices and tools used in the research:

- Restameter to measure the total height of the body in $\mathrm{cm}$. 
- Standardized medical balance to measure weight in $\mathrm{kg}$.

- Dynamometer to measure the strength of muscles of legs and back.

- A number of computers.

- A number of compacted CD.

- Wooden ruler graduated in $\mathrm{cm}$.

- A digital stopwatch to $1 / 100$ of second supplied with memory.

- Legal track with its tools.

II. Physical tests under investigation:

1- Test of $800 \mathrm{~m}$ run.

2- Test of leg muscle strength.

3- Test of back muscle strength.

4- Test of standing start (50) m. sprint.

5- Test of calipers aperture front.

6- $\quad$ Barrow's method zigzag running test for agility.

7- $\quad$ Test of standing on a long wooden piece.

III. Evaluation of the level of technical performance in athletic walking event under investigation:

The level of technical performance was evaluated by using a special evaluation form for athletic walking event as its items concluded phases of the technical performance of athletic walking event. The form was presented to a group of experts in field and track events to carry out necessary modifications suiting the main research sample individuals, to place the total score of the form and distribute it to each item in its content. The total items is (10) scores. A judgment committee of (3) professors of field and track events at Faculty of Physical Education for Girls, Zagazig University evaluated the level of technical performance in athletic walking event for girls before and after the experiment.

IV. Measuring the numerical level in athletic walking under investigation:

The researcher requested a committee of female judges and lane observers of teaching board members and their assistants in Dept. of Field and Track Events, Zagazig University.

The researcher considered that female assistants understand rules of athletic walking 
events to observe girls throughout the time of the event to judge the success of the event for each girl. Time was computed for $(2 \mathrm{~kg})$ by outlining a committee of the oldest three professors in the department and the average of the 3 times was calculated to assure of accuracy. The numerical level was measured for the event in minutes by using tools available in the research experiment in condition that no violations were committed in the event. V. Higher IQ test:

Al-Sayed Mohammed Khairy (1987) (9) prepared such test which was special for measuring intelligence in academic students. The test consists of (42) questions.

The educational program by using e-mind maps:

I. The objective of the educational program:

1- Learning athletic walking event for girls in the $2^{\text {nd }}$ grade, at Faculty of Physical Education for Girls, Zagazig University.

II. Foundations of
placing the educational
program:
$1-\quad$ The learner is to work on the computer, to select from the list of contents and to get into branches inside the program herself according to the level of learning targeted for achievement.

2- Presenting all figures, images and video clips by computer together with the cognitive text.

3- Considering

connecting the main branches with the central idea since this connection helped remember it easily.

4- Considering

branches should be in a curved form instead of straight lines which affect the mind with boredom whereas curved branches like branches of trees are more attractive to eyes and more exciting to their attention. 5- Using a figure or an image to express the central idea.

6- The content of the program should be graded from easiness to difficulty according to girls' abilities.

7- Considering lines should be connected and nonintermittent and the central lines should be more thick than branching lines, as far we are from the center the less thickness of lines. 
8- Considering the use of multicolor in the whole map during drawing as colors excite the mind like images.

\section{The content of the educational program:}

The content of the educational program by using e-mind maps included some key themes like athletic walking event and some branches are emerged to form the e-mind maps such as front support phase, back support phase, back swing phase, front swing $d$ phase and double support phase. Under each branch educational steps are listed and exercises graduated from the simple to the complex.

IV. Tools necessary for the educational program: 1- A number of computers.

2- Mind Meister program to draw e-mind maps. V. Carrying out the proposed educational program:

When applying the content of the educational program by using e-mind maps the following points were considered:

1- Educational steps, exercises and technical aspects of athletic walking event were recorded on a $\mathrm{CD}$ through the multimedia that teaching was done with using the educational program to the experimental individuals.

2- The traditional method was applied to the control group individuals that the technical points were explained and a practical example of athletic walking event and its phases was presented by the teacher then learners carried out the performance only.

3- The researcher taught the experimental and the control groups.

VI. Time distribution for the educational program: 1- Total number of weeks was (4) weeks that was the duration of applying the experiment.

2- $\quad$ Time allocated for each educational unit was (90) min.

3- Two educational units were outlined per week.

4- The program included total of (8) educational units.

Pre-measurements:

\begin{tabular}{llr}
\multicolumn{2}{c}{ The } & \multicolumn{2}{r}{ researcher } \\
conducted the pre- & for the
\end{tabular}


experimental and control groups in the level of technical and numerical performance in athletic walking event $(2 \mathrm{~km})$ in the period from $10 / \mathrm{r} / 2015$ to I $\mathrm{V} / \mathrm{r} / 2015$.

Applying the proposed educational program:

The content of the educational program was applied by using e-mind map for (4) continuous s weeks by two educational units a week for (90) min. per each unit in the period from $r r / 3 / 2015$ to $1 \tau / \varepsilon / 2015$ in the meantime, the traditional method was used with the control group.

Post-measurements:

They

were

conducted for the experimental and control groups in the level of technical and numerical performance $(2 \mathrm{~km})$ with the same order and conditions of the pre-measurements in the period from $19 / \Sigma / 2015$ to r) $/ 4 / 2015$.

Presentation and discussion of the results:

1- Presentation and discussion of the results of the $1^{\text {st }}$ hypothesis:

Table (5)

Significance of differences between the pre and postmeasurements of the experimental group in the level of technical and numerical performance in athletic walking event $n=15$

\begin{tabular}{|c|c|c|c|c|c|c|}
\hline \multirow[t]{2}{*}{ Variables } & \multirow[t]{2}{*}{ Unit } & \multicolumn{2}{|c|}{$\begin{array}{c}\text { Pre- } \\
\text { measurements }\end{array}$} & \multicolumn{2}{|c|}{$\begin{array}{r}\text { Post- } \\
\text { measurements }\end{array}$} & \multirow[t]{2}{*}{$t$ value } \\
\hline & & $\mathrm{X}^{-}$ & SD & $\mathbf{X}^{-}$ & SD & \\
\hline $\begin{array}{l}\text { The level of technical } \\
\text { performance in } \\
\text { athletic walking } \\
\text { event }\end{array}$ & Score & $1 . r$. & $\cdot . \wedge r$ & ^.^. & .00 & $* r \leqslant .91$ \\
\hline $\begin{array}{l}\text { The numerical } \\
\text { level in athletic } \\
\text { walking event }\end{array}$ & Min & דז.זו & $\because \vee 9$ & 11.79 & $\cdot . \wedge r$ & *0.r \\
\hline
\end{tabular}

Tabulated $t$ value at 0.05 level of significance $=2.145$.

* Significant at 0.05 level

Data in Table (5) show that there are significant differences at the 0.05 significance level between the pre and post-measurements of the experimental group in the level of technical and numerical performance in 
athletic walking event in favor of the post-measurement.

The researcher attributed the improvement in the level of technical and numerical performance in athletic walking event in the experimental group individuals to the positive effect of using the strategy of e-mind maps included educational steps, graduated exercises and technical phases of athletic walking event that gave a complete perception for the event to be learned through the content of strategy of educational video footage, fixed images and animations contributing to increase girls motivation to learn educational steps of athletic walking event. Also the researcher related this improvement to navigation in e-mind maps of athletic walking event by the learner of searching, wandering, discovering and demonstrating leading to increase the amount of mental effort exerted by the girl during learning with the result that she had more ability to visualize and attention concentration on details of motion during walking event in addition to evaluation processes after each educational unit to make the girl know her true level and the amount of achievement.

This result agreed with those of Lila Sharaf AlDin Emam (2012) (5), Tamer Gamal Arafa (2015) (2), Joseph Nagy Adib (2015) (22), Sohail Mohammed Al-Sayed (2015) (24), Shady Mohammed AlArabi (2015) (25), Nehad Mohammed Elwan and Nabil Kazem Heribd (2015) (16) of the importance of using e-mind maps in mastering motor skills in learners.

Also this result was in harmony with those of Ozdilek \& Ozkan (2009) and Ahlberg \& Ahoranta (2012) (18) of the importance of using e-mind maps in planning, teaching and briefing the lesson material and they could be used as a tool to evaluate the lesson at the end of the educational unit and they were greatly important for both the learner and the teacher as they help the learner search for relationships among concepts and aspects of similarities and differences among them, relate new concepts with previous ones and develop educational examples leading to improve 
achieving performance in learners.

$$
\text { Buzan (2006) added }
$$

that the e-mind map was an active educational strategy working to connect information read in books by developed technological means in the form of a map, to turn the readable idea into a map containing brief figures incorporated with colors and forms in a $\mathrm{CD}$ to give the

\section{Table (6)}

Significance of differences between the pre and postmeasurements of the control group in the level of technical and numerical performance in athletic walking event $\quad n=15$

\begin{tabular}{|c|c|c|c|c|c|c|}
\hline \multirow[t]{2}{*}{ Variables } & \multirow[t]{2}{*}{ Unit } & \multicolumn{2}{|c|}{$\begin{array}{c}\text { Pre- } \\
\text { measurements }\end{array}$} & \multicolumn{2}{|c|}{$\begin{array}{r}\text { Post- } \\
\text { measurements }\end{array}$} & \multirow[t]{2}{*}{$t$ value } \\
\hline & & $\mathbf{X}^{-}$ & SD & $\mathbf{X}^{-}$ & SD & \\
\hline $\begin{array}{l}\text { The level of technical } \\
\text { performance in } \\
\text { athletic walking } \\
\text { event }\end{array}$ & Score & $1 . T V$ & .91 & V.qT & $\cdot V V$ & $* Y 1 . \leqslant 7$ \\
\hline $\begin{array}{l}\text { The numerical } \\
\text { level in athletic } \\
\text { walking event }\end{array}$ & Min & & .77 & Ir.YA & $.0 \leqslant$ & $* Y .19$ \\
\hline
\end{tabular}

Tabulated $t$ value at 0.05 level of significance $=2.145$.

* Significant at 0.05 level.

Data in Table (6) illustrate that there are significant differences at 0.05 significance level between the pre and post-measurements of the control group in the level of technical and numerical performance in athletic learner a wide area of thinking and to give him a chance to review his previous information on the theme and to fix new data and information in mind knowledge areas (27:107). Consequently, the validity of the $1^{\text {st }}$ hypothesis is established.

1- Presentation and discussion of the results of the $2^{\text {nd }}$ hypothesis: 
learning technique built on presenting verbal explanation and performing the practical example by the teacher then the girl should perform and repeat the motor work then presenting feedback and correcting faults by the teacher and all of these aspects provided the girl with a good chance to learn and to master the performance required. The researcher related the current improvement also to the orders-learning technique

\section{Table (7)}

which became familiar to girls for their studying life in addition to girls learning in groups which stimulated their motivation to compete to show their superiority with the result that girls had to perform athletic walking event very well and this could achieve the validity of the $2^{\text {nd }}$ research hypothesis.

I. Presentation and discussion of the $3^{\text {rd }}$ hypothesis:

Significance of differences between the two post-measurements of the experimental and control groups in the level of technical and numerical performance in athletic walking event

\begin{tabular}{|c|c|c|c|c|c|c|}
\hline \multirow[t]{2}{*}{ Variables } & \multirow[t]{2}{*}{ Unit } & \multicolumn{2}{|c|}{$\begin{array}{l}\text { Experimental } \\
\text { group } n=15\end{array}$} & \multicolumn{2}{|c|}{$\begin{array}{l}\text { Control } \\
\text { group } \\
\mathrm{n}=15\end{array}$} & \multirow[t]{2}{*}{$\begin{array}{c}t \\
\text { value }\end{array}$} \\
\hline & & $\mathbf{X}^{-}$ & SD & $\mathbf{X}^{-}$ & SD & \\
\hline $\begin{array}{l}\text { The level of technical } \\
\text { performance in } \\
\text { athletic walking event }\end{array}$ & Score & $\wedge . \wedge$. & .00 & V.qT & $\because V V$ & $* T . \varepsilon \varepsilon$ \\
\hline $\begin{array}{l}\text { The numerical level in } \\
\text { athletic walking event }\end{array}$ & Min. & 11.79 & $\cdot . \wedge r$ & IT. KA & $.0 \leqslant$ & *Y. Yo \\
\hline
\end{tabular}

Tabulated $t$ value at 0.05 level of significance $=2.048$.

* Significant at 0.05 level.

Data in Table (7) show that there are significant differences at 0.05 significance level between the two postmeasurements of the experimental and control groups in the level of technical and numerical performance in athletic walking event in favor of the experimental group.

The researcher related the superiority of individuals of the experimental group to individuals of the control group in the level of technical and numerical performance in athletic 
walking event to the use of emind maps that considered one of the modern teaching techniques in supporting the educational process as such techniques helped girls form visualization of performance of athletic walking event through the content of e-mind maps of educational steps and graded exercises, complete explanation of technical aspects and how to correct common faults through evaluation processes after each educational unit and all of these aspects positively contributed to master phases of the technical performance of movements in athletic walking event.

In the meantime, Buzan (2006) indicated that the use of the strategy of e-mind maps transmitted the spirit of excitement in the student leading to make him more cooperative and ready to receive knowledge. The strategy also made lessons and presentations more spontaneous, creative and enjoyable for both of the student and the teacher and consequently, they constituted a great chance for the student to get better scores in tests because the mind maps represented the book material in a clearer, memorable, brief and not branched form. They were characterized by showing facts together with relationships among them consequently, they established meaningful learning. Also mind maps represented a special importance of learners suffering from learning difficulties.(27:218)

\section{Table (8)}

Percentage of improvement of the post-measurement for the premeasurement for the experimental and control groups in the level of technical and numerical performance in athletic walking event

\begin{tabular}{|c|c|c|c|c|c|c|}
\hline \multirow[b]{2}{*}{ Variables } & \multicolumn{3}{|c|}{ Experimental group $n=15$} & \multicolumn{3}{|c|}{ Control group $n=15$} \\
\hline & Pre & Post & $\begin{array}{c}\text { Improvement } \\
\%\end{array}$ & Pre & Post & $\begin{array}{c}\text { Improvement } \\
\%\end{array}$ \\
\hline $\begin{array}{l}\text { The level of } \\
\text { technical } \\
\text { performance in } \\
\text { athletic } \\
\text { walking event }\end{array}$ & $1 . r$. & ^.^. & 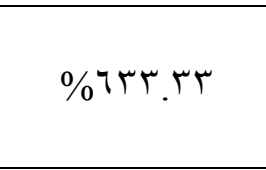 & $1 . r V$ & V.9T & $\% \circ r \leq \leq 1$ \\
\hline $\begin{array}{l}\text { The } \\
\text { numerical } \\
\text { level in } \\
\text { athletic }\end{array}$ & דז. זו & 11.79 & $\%) \leq .4 q$ & IT.Y & IT.YA & $\% \vee . \wedge r$ \\
\hline
\end{tabular}

Assiut Journal For Sport Science Arts 


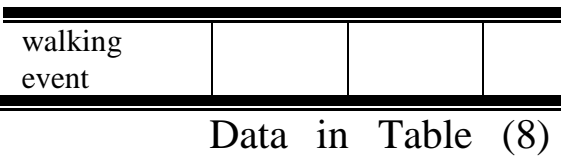

illustrate that the experimental group individuals are superior to the control group individuals in the percentage of improvement of the post measurement for the premeasurement in the level of technical and numerical performance in athletic walking event.

This result agreed with that of Tucker (2008) (28) that mind maps were characterized by their benefits for the learner to reach the highest level of concentration and they turned the written material into an easy arrangement to understand represented by the layout of the mind map that was also helped arrange and order ideas of the learner because they were a planning arrangement of the scientific material, ideas and information technically and visually to provide the learner with the chance to react with the scientific material. They were also working to incorporate learners actively into the educational process. Hence, this could achieve the $3^{\text {rd }}$ hypothesis.

\section{Conclusions:}

1- The use of e-mind maps had a significantly positive effect at the 0.05 level on the level of technical and numerical performance in athletic walking event for girls in the $2^{\text {nd }}$ grade at Faculty of Physical Education, Zagazig.

2- The use of orders-learning technique had a significantly positive effect at 0.05 significance level on the level of technical and numerical performance in athletic walking event for girls in the $2^{\text {nd }}$ grade at Faculty of Physical Education, Zagazig.

3- E-mind maps were more effective than orders-learning technique in the level of technical and numerical performance in athletic walking event.

4- Individuals of the experimental group were superior to those of the control group in percentages of improvement of the postmeasurement for premeasurement in the level of technical and numerical performance in athletic walking event.

Recommendations: 
In the light of the current research results, the researcher recommended the following:

1- E-mind maps should be used to up-grade the level of technical and numerical performance in athletic walking event for girls in the $2^{\text {nd }}$ grade at Faculty of Physical Education, Zagazig.

2- Women in-charge of teaching field and track events at Faculty of Physical Education, Zagazig should consider that the learner should have an active role in the educational process particularly in the present time that is the information age and the cognitive enrichment.

3- Training courses should be held for the teaching board members and their assistants at faculties of physical education on how to use e-mind maps to teach subjects of fields and track events.

4- Necessary facilities and possibilities such as laboratory, devices and programs of emind maps should be provided in Depts. of Field and Track Events at faculties of physical education.

5- Similar studies with e-mind maps should be conducted to develop different aspects in courses of field and track events for girls at faculties of physical education.

\section{References}

1- Ahlberg, M. \& Ahoranta, V.,(2012): Two Improved Educational Theory Based Tools to Monitor and Promote Quality of Geographical Education and Learning. International Research in Geographical and Environmental Education, 11,(2), 119-137.

\section{2- Afaf Abdel Karim Hassan}

(1994): Methods of Teaching in Physical and Sports Education. Knowledge Facility (Monshaat Al-Maaref), Alex.

\section{3- Al-Sayed Mohammed} Khairy (1998): Higher IQ Test (Instruction and Applications), Arab Renascence House, Cairo.

4- Buzan, T., (1995): The mind Map Book. 2nd edn, BBC Books: London.

5- Buzan, T., (2002): How To Mind Map. London : Thorons.

6- Buzan, T., (2006): Mind Mapping Kick Start Your Creativity And Transform Your Life. Spin, Mateu Cromo. 7- Eppler, J., (2006): A comparison between concept maps, mind maps, conceptual 
diagrams and visual metaphors as complementary tools for knowledge construction and sharing. Journal Of Information Visualization, $5(3)$.

8- Gerry Carr (1999) : Track and field, human kinetics, USA.

9- Hassan Hussein Zaitoun (2003): Teaching Strategy: Contemporary Vision of Teaching and Learning. The World of Books.

10- International Association of Athletics FederationsInternational Law 2004): Rules of Competition. 2nd Ed.

\section{1- Joseph Nagy Adib} (2015): Effect of using concepts programed maps on learning some basic skills in table tennis. Journal of Physical Education Researches, Vol. (53), No. (99), Part (5), Faculty of Physical Education for Boys, Zagazig University.

13- Lila Al-Sayed Farahat (2003): Measurement and Testing in Physical Education, 2nd Ed. Book Publication Center, Cairo.

14- Lila Sharaf Al-Din Emam (2012): The effectiveness of using e-mind maps on cognitive attainment and its relationship to the level of skill performance in motor dance. Vol. (42), Journal of Physical Education Arts and Sciences, Faculty of Physical Education for Girls, Helwan University.

15- Magdi Aziz Ibrahim (2002): Effective Teaching What it is - Its skills- its management. Anglo Egyptian Bookstores, Cairo.

\section{6- Mahdi Mahmoud Salem} (2002): Technologies and Means of Education. Arab Thought House (Dar Al-Fekr Al-Arabi.

17- Mohammed Hassan Allawi \& Mohammed Nasr El-Din Radwan (2001): Tests of Motor performance. Arab Thought House (Dar Al-Fekr Al-Arabi), Cairo.

18- Mohammed Saad Zaghloul, Makarem Helmi Abo Harga and Hani Said Abdel Menem (2001): Education Technology and Its Techniques in Physical Education. Book Publication Center, Cairo.

19- Mohsen Mohammed Homos (1997): Leader in Teaching Physical Education. Knowledge Facility, Alex.

20- Mostafa Abdel Samie, Mohammed Lotfy \& Saber Abdel Menem (2001): 
Communication

and

Educational Means, Essential Readings for Teacher Student. Book Publication Center, Cairo.

21- Naguib Al-Refaei (2009): Mind Map Step by Step. 2nd Ed. Line Press, Kuwait.

\section{2- Nehad Mohammed} Elwan \& Nabil Kazem Heribd (2015): Effect of multimedia supported mind maps strategy on developing motor sensory IQ and accuracy of shot from corners for young handball players. Journal of Babel University for Humanities, Vol. (23), No. (4), Iraq.

23- Ozdilek, Z., \& Ozkan, M., (2009): The Effect of Applying Elements Of Instructional Design on Teaching Material for the Subject of Classification of Matter, Turkish Online Journal of Educational Technology, 8 (1).

24- Ruffini Michael (2011) : Using e- maps to organize and navigate on line content, Educause Quarterly Magazine, 31(1), 56-61.

25- Shady Mohammed AlArabi (2015): Effect of using mind maps to teach some basic skills in boxing young players.
M. Sc. Thesis, Faculty of Physical Education, Banha University.

26- Sohail Mohammed AlSayed (2015): Using mind maps to teach some basic skills for young basketball players. M. Sc. Thesis, Faculty of Physical Education, Banha University.

27- Tamer Gamal Arafa (2015): The effectiveness of using strategy of concepts programed maps on learning some basic skills in fencing. Journal of Physical Education Researches, Vol. (53), No. (99), Part 2. Faculty of Physical Education for Boys, Zagazig University.

28- Tony Buzan (2007): Use Your Mind. Translated by Garir, Riyadh, K. S. A.

29- Tucker, et.,al., (2008): Profiling A Mind Map User: A Descriptive Appraisal. 